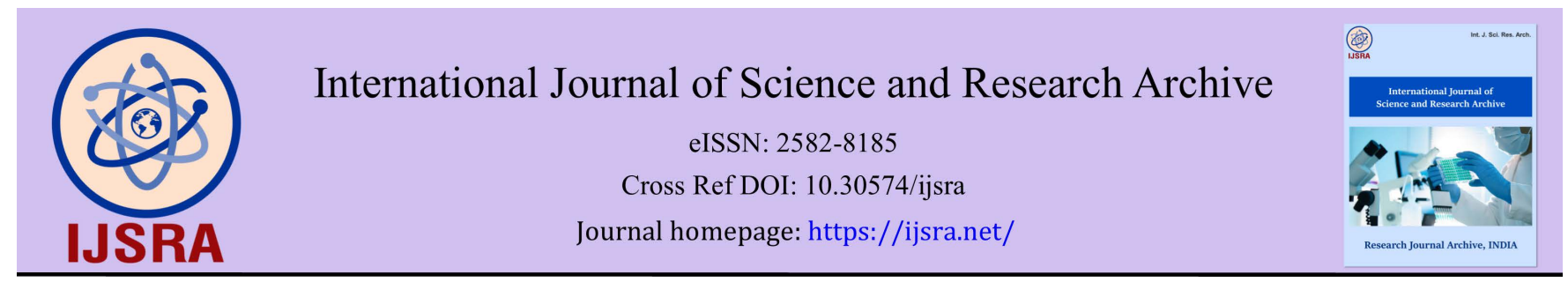

(RESEARCH ARTicle)

\title{
Assessing the antiumer and anti-inflammatory potentials of Calotropis procera latex
}

\author{
Ruqaya Mohammed Al-ezzy 1, ${ }^{*}$, Asmaa Sabah Ahmaed 2, Nidhal Mohammed Saleh ${ }^{2}$ and Shaymaa Hameed \\ Al-Obaidy 2
}

${ }^{1}$ College of Biotechnology, Al-Nahrain University, Baghdad, Iraq.

${ }^{2}$ College of Agricultural Engineering Sciences|University of Baghdad|Baghdad|Iraq.

International Journal of Science and Research Archive, 2021, 04(01), 086-091

Publication history: Received on 16 October 2021; revised on 25 November 2021; accepted on 27 November 2021

Article DOI: https://doi.org/10.30574/ijsra.2021.4.1.0183

\begin{abstract}
Since time immemorial medicinal plants have been used in healthcare to treat different human disease. The ideals of medicinal plants are highlighted due to the utility of the common-factor approach to engage other health promoters in propagating. One of these medicinal plants is Calotropis procera which is a species of tree in the family Apocynaceae. Calotropis procera is widespread in tropical Africa, including the Indian Ocean islands and the northern parts of South Africa. The latex is toxic and can cause rash, blisters and serious inflammations in sensitive persons and it may lead to blindness. Several side effects may be caused due to ingestion large doses of latex like burning in the throat, irritation of the stomach, nausea, vomiting, diarrhea, tremors, vertigo and convulsions. This study aimed to evaluate burns healing effects and inhibitory concentration $\mathrm{IC}_{50}$ of Calotropis procera latex on cervical cancer cell line, SiHa. Cytotoxicity analysis was performed by MTT assay in addition to determine the burns healing effect of the latex by determining the day requiring to heal the burn skin of albino male mice. The results of burns healing effects declared that the burns required 12 days to heal in comparison with positive (sliver sulfadiazine) and negative control which required 16 and 18 days for healing respectively. Also, the results revealed that the $\mathrm{IC}_{50}$ of latex was $146.8 \%$ in comparison of ambiguous percentage of normal cell line WRL68 with reduction in cancer cell viability ranging from $95.87 \pm 0.20$ to $52.35 \pm 3.31$ for 6.2 to $400 \mu \mathrm{g} \backslash \mathrm{ml}$ respectively.
\end{abstract}

Keywords: Calotropis procera; Latex; SiHA cell line; Burns healing; Anticancer

\section{Introduction}

The plant Calotropis procera R. Br. (Asclepiadaceae) used medicinally in past decades in traditional systems due its medicinal important especially, to care for boils, infected wounds and other skin problems in people. Also, this plant had numerous pharmacological activities like: Analgesic, hepatoprotective, anti-diarrhoeal, antidiabetic, antimalarial, antinociceptive, anti-inflammatory, anthelmintic, anticonvulsant, antimicrobial, anticancer, antifertility and antioxidant activity (1). Calotropis procera is widespread in tropical Africa, including the Indian Ocean islands and the northern parts of South Africa (2). This plant is prevalently known because it large quantity of latex that produced. The latex from C. procera consists of about high percentage of water (88-93\%) and water soluble compounds. The chemical screening of its latex revealed that this plant contain cardinolides such as calotropin, calotoxin, uscharin, uscharidin, voruscharin (3). Latex is used as nose drops to induce sneezing to reduce headache. The latex is the richest in cardenolides and contains as main cardenolides uscharin (which has been patented to combat uncontrolled cell proliferation), calotropagenin, uscharidin, uzarigenin, calotropin, calotroposide, calactin, calotoxin, voruscharin, ascleposide, coroglaucigenin, proceroside, proceragenin and syriogenin (4). The quantities of cardenolides in the stem, fruit, leaves and root bark are different from the quantities found in the latex (5). The main cardenolides of the latex are uscharin

\footnotetext{
${ }^{*}$ Corresponding author: Ruqaya Mohammed Al-ezzy

College of Biotechnology, Al-Nahrain University, Baghdad.
}

Copyright (C) 2021 Author(s) retain the copyright of this article. This article is published under the terms of the Creative Commons Attribution Liscense 4.0. 
and calotropagenin, from the stem uscharidin, calotropin and proceroside, of the leaves calotropin and calotropagenin, of the fruit pericarp coroglaucigenin, uzarigenin and calactin, and of the root bark calotoxin and calactin (6).

\section{Material}

\subsection{Calotropis procera latex collection and identification}

C. procera was growing in wild and identified as Raw Materials. The latex was collected from the agricultural fields of the University of Baghdad where the trees of $C$. procera are located and the aerial parts of the plant used to collect sample by cutting the leaves from the stem, so the material goes down from the place of the pieces and collected in a sterile syringe and kept for further studies.

\subsection{Experimental Animals}

Albino Swiss male mice (Mus musculus) (23-25 g weight) and (8-10 weeks age) used in this study. These animals were free access to food. The experiments were performed as per the guidelines of the Biotechnology Research Centre $\backslash \mathrm{Al}$ Nahrain University. Each group of mice contains 4 animals put in a separate plastic cage and the room temperature ranged between of $23-25^{\circ} \mathrm{C}$, relative humidity $30-50 \%$.

- Group one: treated with Calotropis procera latex.

- Group two: Positive control treated with sliver sulfadiazine (SSD) at concentration 1 sliver sulfadiazine cream.

- Group three: Negative control without any treatment.

\subsection{Burns skin modle in mice (7)}

The hairs of mice were removed by machine and hair removal cream, and wounded by using flames source to get the burns. Then mice were cured by using Calotropis procera latex and sliver sulfadiazine cream (1\%) by continuously used until complete curing of mice.

\subsection{Estimation of antitumor activity by MTT Assay}

In order to assess the antitumor activity of latex, MTT assay was used through using ready to use kit followed the procedure of (8).

Briefly, tumor cells (1x10 $4-1 \times 106$ cells $/ \mathrm{mL})$ were grown in 96 flat well micro-titer plates to a final volume of $200 \mathrm{~mL}$ complete culture medium per all well. After enclosed the plate by sterilized parafilm, incubated at $37^{\circ} \mathrm{C}, 5 \%$ CO 2 for 24hrs. After that, the medium was removed and Calotropis procera latex was added to the wells at different concentration ranged from $(6.2-400 \mu \mathrm{g} \backslash \mathrm{ml})$, then Plates were incubated at $37^{\circ} \mathrm{C}, 5 \% \mathrm{CO} 2$ for 24 hours followed by addition of $10 \mathrm{ml}$ of the MTT solution was added. After that plates incubated at $37^{\circ} \mathrm{C}, 5 \% \mathrm{CO} 2$ for 4 hours. Then, media were carefully removed and solubilization solution $(100 \mathrm{~mL})$ added per each well. After $5 \mathrm{~min}$, the plates were examined using an ELISA reader at a Wave length of $575 \mathrm{~nm}$ to evaluate the concentration of compounds required to cause $50 \%$ reduction in cell viability for each cell line.

\subsection{Statistical analysis}

One-way ANOVA was used to measure significance differences ( $\mathrm{p}<0.05$ considered significant).

\section{Results and discussion}

\subsection{Burns healing effect}

To explore the anti-inflammatory activity of Calotropis procera latex, burns healing effect was assessed. The activity of latex was investigated in compared with sliver sulfadiazine as positive control and negative control by determining days require for healing (Table 1). The results showed that Calotropis procera latex had the ability to heal burns in 12 days (Fig 1) in compared to 14 days for sliver sulfadiazine and negative control which require 16 days to heal the burns. 


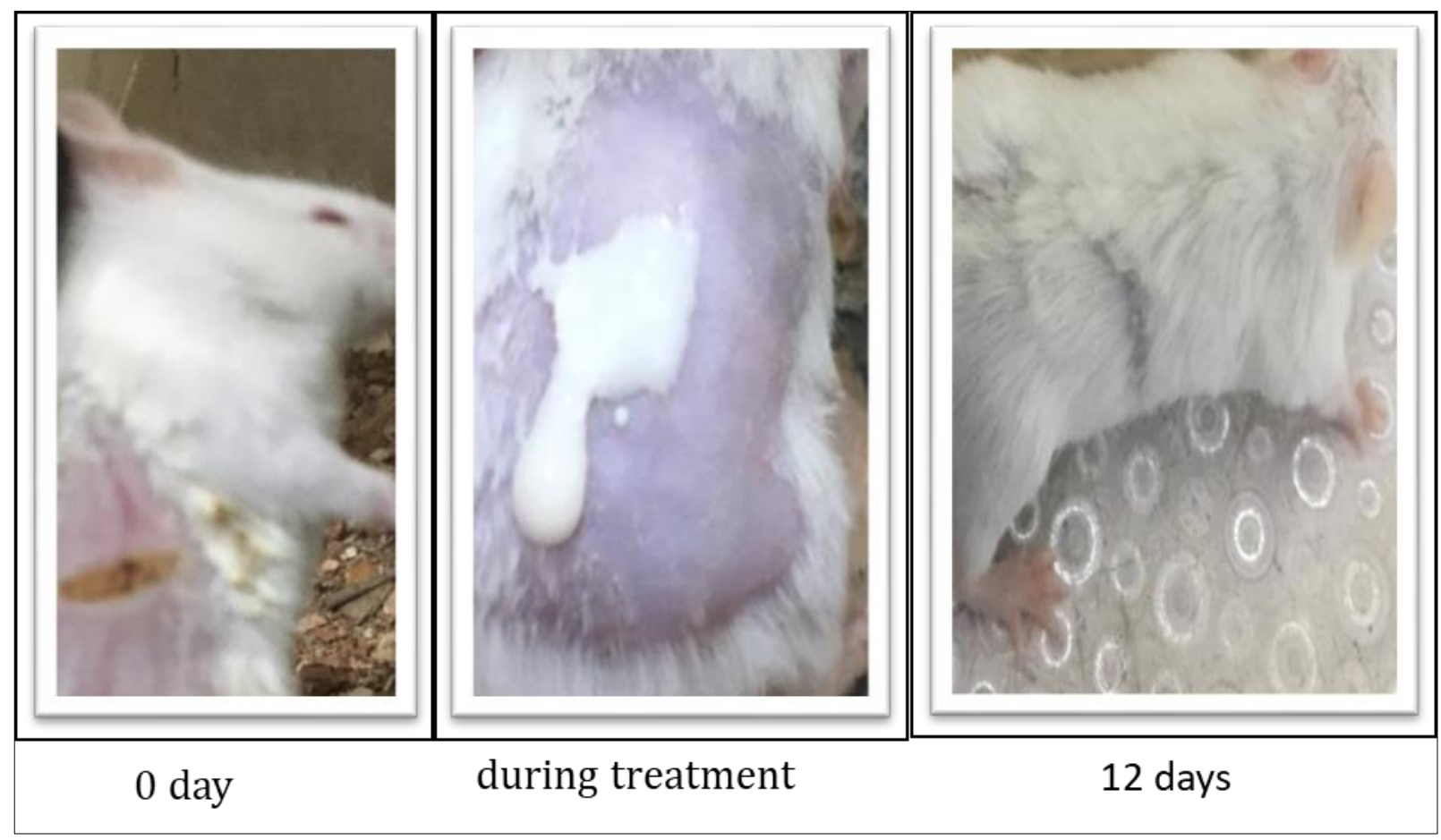

Figure 1 Picture showed mice healed from burns on (0 and 12) days after treatment with Calotropis procera latex

Table 1 The discovery of burn healing considered by days required for healing

\begin{tabular}{|l|l|c|}
\hline Groups & Treatment & Period of recovery \\
\hline Group 1 & Calotropis procera latex & Days 12 \\
\hline Group 2 & Sliver sulfadiazine & Days 14 \\
\hline Group 3 & without any treatment & Days 16 \\
\hline
\end{tabular}

\subsection{Cytotoxic Effect of Calotropis procera latex on cervical cancer cell line (SiHa) in vitro using MTT Assay}

Cervical cancer cell line, SiHa used to evaluate the cytotoxicity of latex in compare with normal cell line. This assay measured both the cell viability and inhibition rate of cancer cell and normal cell WRL68 (fig 2).

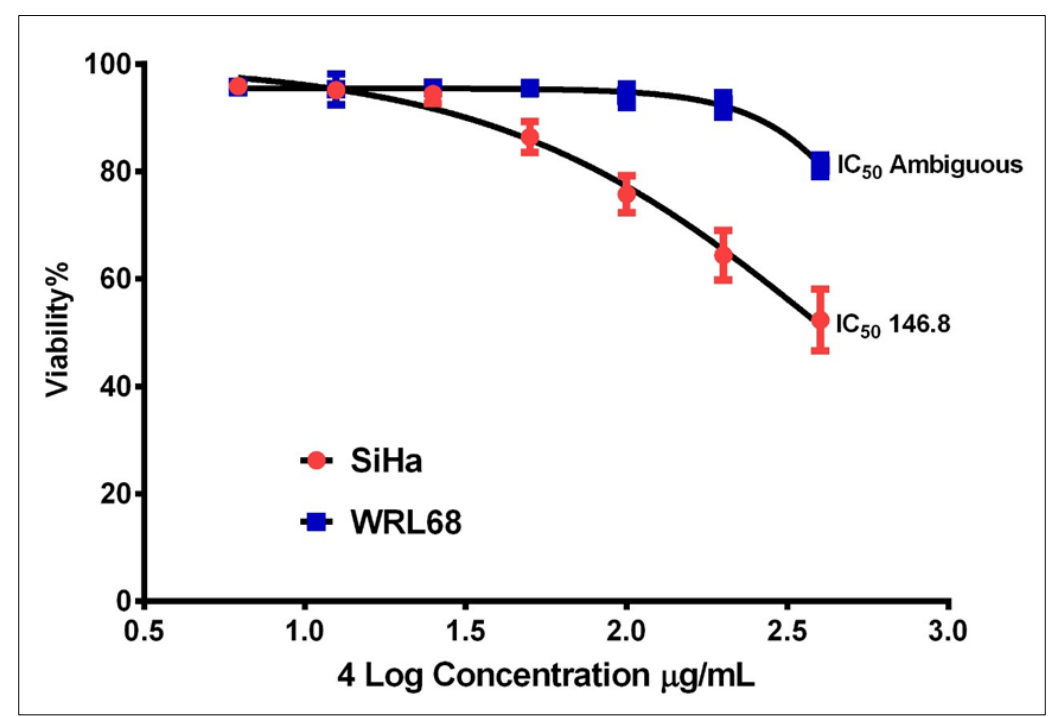

Figure 2 Cytotoxic activity of Calotropis procera latex against SiHa and WRL-68 cell lines 
Different concentrations of Calotropis procera latex used in this study ranged from 6.2 to $400 \mu \mathrm{g} / \mathrm{ml}$. Results of indication of of SiHa cells for 24 hours with latex showed a reduction in cell viability in a dose-dependent pattern (i.e. the cell viability decreased by increase the concentration of latex) as shown in table 2 in which the viable cell count only $52.35 \pm 3.31$ at $400 \mu \mathrm{g} / \mathrm{ml}$. The lowest SiHa cell viability (\%) was noted by latex at concentration $400 \mu \mathrm{g} / \mathrm{ml}$. It was detected significant differences in the rate of SiHa cell inhibition between the different concentrations by measuring the IC50 which was $146.8 \%$ in comparison of ambiguous inhibition percentage of normal cell line WRL68.

Table 2 Cytotoxicity effect of Calotropis procera latex on cell viability of SiHa cells after 24 hours incubation at 37으.

\begin{tabular}{|c|c|}
\hline Latex Concentrations $(\boldsymbol{\mu g} \backslash \mathbf{m l})$ & $\begin{array}{l}\text { Viable cell count of SiHa cells line } \\
\text { (Mean } \mathbf{S} \text { S.D.) }\end{array}$ \\
\hline 400 & $52.35 \pm 3.31$ \\
\hline 200 & $64.39 \pm 2.66$ \\
\hline 100 & $75.77 \pm 1.99$ \\
\hline 50 & $86.42 \pm 1.67$ \\
\hline 25 & $94.41 \pm 0.96$ \\
\hline 12.5 & $95.01 \pm 0.57$ \\
\hline 6.2 & $95.87 \pm 0.20$ \\
\hline
\end{tabular}

\section{Discussion}

Pharmacologically plant extracts are of great importance in anticancer and anti-inflammatory research (9). Numerous studies on extracts from C. procera have been carried out in recent years documenting the anticancer potential of different part of this medicinally important plant (10).

Inflammation is the rejoinder of the tissue to provide guard against injury and comprises of both vascular and cellular events. It included various mediators and also infiltration of leukocytes and generation of diverse cytokines at the site of injury $(11,12)$. The two phases of anti-inflammatory response are (early) phase which caused direct stimulation and release of some substance in the site of injury or the late phase which release of histamine, serotonin, bradykinin and prostaglandins (13). Latex may interact with opioid receptors and reduced period of itching and burns in burns mice; the specific antagonist for opioid receptors (14). The mechanism of anti-inflammatory action of latex is as for the analgesic effect of drug through inhibition of both phases of response in both centrally and peripherally mechanisms of analgesia. Also, antioxidant properties of latex of $C$. procera in vitro attributed to scavenge free radical (ROS) which formed in the body (16) because of high molecular weight proteins that produce antioxidant effect and treat the inflammatory conditions by significantly inhibits edema formation (17).

As our results indicate that latex was effective against inflammation induced by histamine and hold back its releasing from the mast cells in addition to inhibition of cellular infiltration especially neutrophill (18). The pro-inflammatory cytokines and reactive oxygen and nitrogen species are activate signaling molecules involved in inflammation and carcinogenesis (19). Latex from C. procera inhibited the viability of cancer cell in addition to possess high degree of selectivity for transformed cells(20). The cytotoxic effect of latex was accompanied by intracellular fragmentation of target cell DNA. Hence a potential role of hypoxia and free radical-dependent activation of DNase activity or direct DNA damage and consequent degradation of cellular DNA (21). These anticancer activity may be owing to Cardiotonic steroid compound which present in C. procera plant which had the ability to induce apoptosis (22) and DNA fragmentation (23).

\section{Conclusion}

Recently many researchers have studied the pharmacological importance of medicinal plants. This is partly due to the fact that these plants have been used for centuries as remedies against different aliments in the traditional medicinal system. Additionally, extracts from these plants have little side effects, making them good candidates for drug development. Our preliminary data substantiate the importance of the C. procera latex as both anti-inflammatory and anticancer agent. Further, in vivo studies are required to shed light on the mode of action of this medicinally important plant and isolation of individual compounds would help in developing treatments with fewer side effects. 


\section{Compliance with ethical standards}

\section{Acknowledgments}

Acknowledgments awarded to the staff of Biotechnology Research Center $\backslash$ Al-Nahrain University for help and support.

\section{Disclosure of conflict of interest}

First author designed the work and idea and wrote the manuscript, the remaining author did the statistical analysis and collected latex and provided animals.

\section{Statement of ethical approval}

This work done after take a permission from the head of animal laboratory house $\backslash$ Biotechnology Research Center $\backslash \mathrm{Al}$ Nahrain University \Baghdad \Iraq.

\section{References}

[1] Manikandan M, Arumugam R. Potentiality of Calotropis procera on the yield of biocrudes and biogas production. Journal of Phytology. 2010; 2(4): 33-40.

[2] Murti Y, Yogi B, Pathak D. Pharmacognostic standardization of leaves of Calotropis procera (Ait.) R. Br.(Asclepiadaceae). Int. J. Ayurveda Res. 2010; 1: 14.

[3] Bagherwal P. Immunomodulatory activities of the non-dialyzable latex fraction (NDL) from Calotropis procera (Ait.) R. Br. International Journal of Research in Pharmaceutical \& Biomedical Sciences. 2011; 2(1): 114-119.

[4] Bharti S, Wahane VD, Kumar VL. Protective effect of Calotropis procera latex extracts on experimentally induced gastric ulcers in rat. Journal of Ethnopharmacology. 2010; 127(2): 440-444.

[5] Moustafa AMY, Ahmed SH, Nabil ZI, Hussein AA, Omran MA. Extraction and phytochemical investigation of Calotropis procera: effect of plant extracts on the activity of diverse muscles. Pharmaceutical Biology. 2010; 48(10): 1080-1090.

[6] Alzahrani HS, Mutwakil MH, Saini KS, Rizgallah MR. Calotropis procera: A Phytochemical and Pharmacological Review with Special Focus on Cancer. Review. 2017; 7: 232-240.

[7] Tian J, Wong KKY, Ho C, Lok C, Yu W, Che C, Chiu J, Tam PKH. Topical delivery of sliver nanopareticles promotes wound healing. Chem Med Chem. 2007; 2(129).

[8] Al-Saffar AZ, Al-Shanon AF, Al-Brazanchi SL, Sabry FA, Hassan F, Hadi NA. Phytochemical Analysis, Antioxidant and Cytotoxic Potentials of Pelargonium Graveolens Extract in Human Breast Adenocarcinoma (MCF-7) Cell Line. Asian Journal of Biochemistry. 2017; 12: 16-26.

[9] Ibrahim RM. Effect of aqueous extract of Rosemary officinalis on cytotoxicity of CCL4 induced albino male mice. Journal of Biotechnology Research Center. 2018; 12: 1.

[10] Akinmoladun AC, Obuotor EM, Farombi EO. Evaluation of antioxidant and free radical scavenging capacities of some Nigerian indigenous medicinal plants. J. Med. Food. 2010; 13: 444- 451.

[11] Soneera A, Vijay LK. Antiinflammatory Efficacy of Extracts of Latex of Calotropis procera Against Different Mediators of InflammationMediators Inflamm. 2005; 31(4): 228-232.

[12] Awasthi TS, Irshad M, Das MK, Ganti SS, Rizvi MA. Anti-inflammatory activity of Calotropis gigantean and Tridax procumbens on carragenaan-induced paw oedema in rats. Ethnobotanical leaflets. 2009; 13: 568 -77.

[13] Laitiff AA, Teoh SL, Das S. Wound healing in diabetes mellitus: traditional treatment modalities. Clin. Ter. 2010; 161: 359-364.

[14] Khulood W Abbood, Ruqaia M, Ibrahim Ali H. Ad'hiah. Antioxidant activity of Hypericum triquetrifolium Turra methanol extract in vitro. International Journal of Medicinal Plants (Photon). 2015; 108: 632-637.

[15] Magalhães HIF, Ferreira PMP, Moura ES, Torres MR, Alves APNN, Pessoa ODL, CostaLotufo LV, Moraes MO, Pessoa C. In vitro and in vivo antiproliferative activity of Calotropis procera stem extracts. An. Acad. Bras. Cienc. 2010; 82: 407-416. 
[16] Alzahrani HS, Mutwakil M, Sabir J, Saini KS, Alarif WM, Rizgallah MR. Anticancer and Antibacterial Activity of Calotropis procera Leaf Extract J. Basic. Appl. Sci. Res. 2017; 7(12): 18-25.

[17] Kumar VL, Chaudhary P, Ramos MV, Mohan M, Matos MP. Protective effect of proteins derived from the latex of Calotropis procera against inflammatory hyperalgesia in monoarthritic rats. Phytother Res. 2011; 25: 1336-41.

[18] Lima-Filho JV, Patriota JM, Silva AFB, Filho NT, Oliveira RSB, Alencar NMN, Ramos MV. Proteins from latex of Calotropis procera prevent septic shock due to lethal infection by Salmonella enterica serovar Typhimurium. J. Ethnopharmacol. 2010; 129: 327-334.

[19] Tour N, Talele G. Anti-inflammatory and gastromucosal protective effects of Calotropis procera (Asclepiadaceae) stem bark. J. Nat. Med. 2011; 65: 598-605.

[20] Chavda R, Vadalia KR, Gokani R. Hepatoprotective and antioxidant activity of root bark of Calotropis procera R.Br (Asclepediaceae). International Journal of Pharmacology. 2010; 6(6): 937-943.

[21] Bulani V, Biyani K, Kale R, Joshi U, Charhate K, Kumar D, Pagore R. Inhibitory effect of Calotropis gigantea extract on ovalbumin-induced airway inflammation and arachidonic acid induced inflammation in a murine model of asthma. Int J Cur Bio Med Sci. 2011; 1(2): 19-25.

[22] Choedon, Mathan G, Arya S, Kumar VL, Kumar V. cytotoxic properties of the latex of Calotropis procera in a transgenic mouse model of hepatocellular carcinoma World J Gastroenterol. 2006; 12(16): 2517-2522.

[23] Oliveira JS, Costa-Lotufo LV, Bezerra DP, Alencar NMN, Marinho-Filho JDB, Figueiredo IST, Moraes MO, Pessoa C, Alves APNN, Ramos MV. In vivo growth inhibition of sarcoma 180 by latex proteins from Calotropis procera. Naunyn. Schmiedebergs Arch. Pharmacol. 2010; 382: 139-149. 